
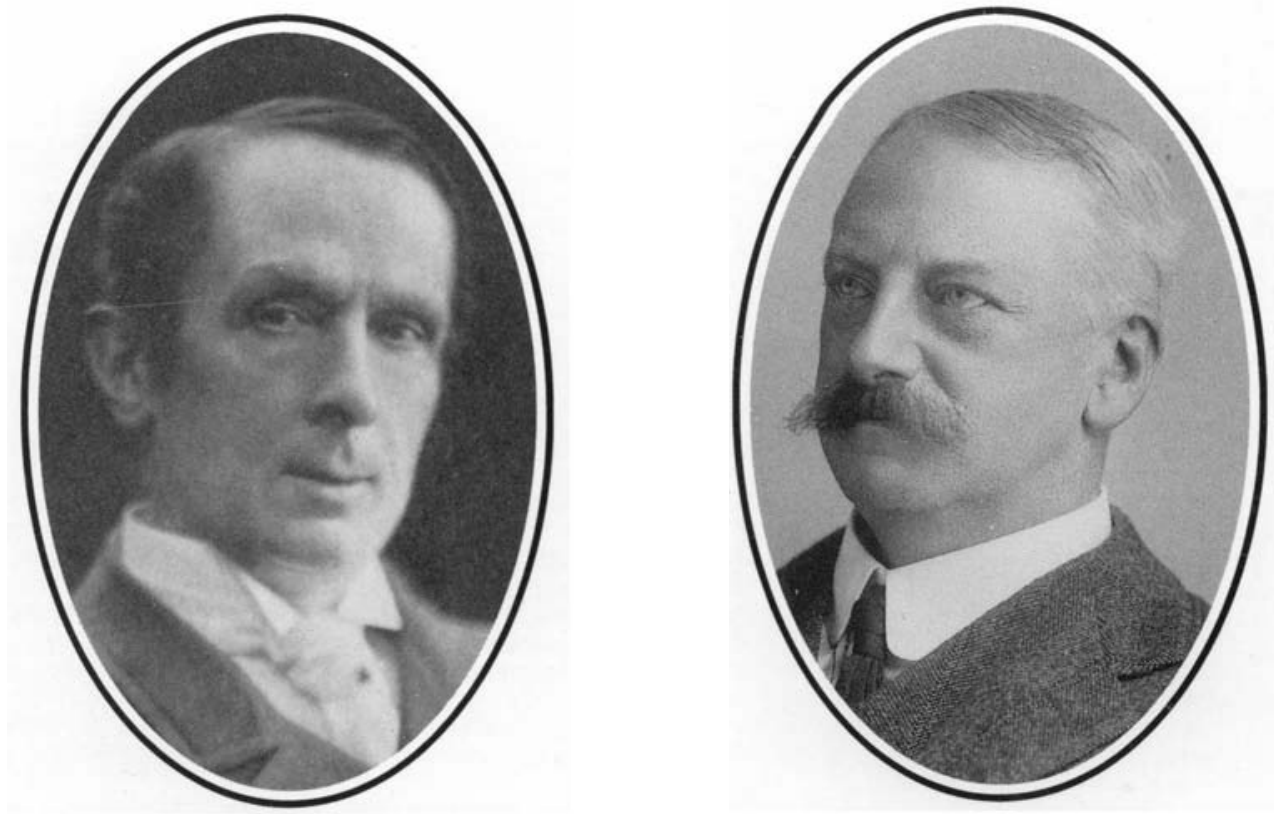

Founded in 1887 by Morell Mackenzie \& Norris Wolfenden

Edited by JOHN B. BOOTH

Assistant Editors NEIL WEIR, PATRICK BEASLEY, CAROL WENGRAF, RICHARD RAMSDEN, IOLO GRIFFITH \& PETER RHŶS EVANS

Advisor in Pathology IMRICH FRIEDMANN

Advisor in Audiology LINDA LUXON

Advisors in Radiology GLYN LLOYD \& PETER PHELPS

Advisor in Statistics STEPHEN EVANS 


\section{NEW FILE BINDERS are now available for The Journal}

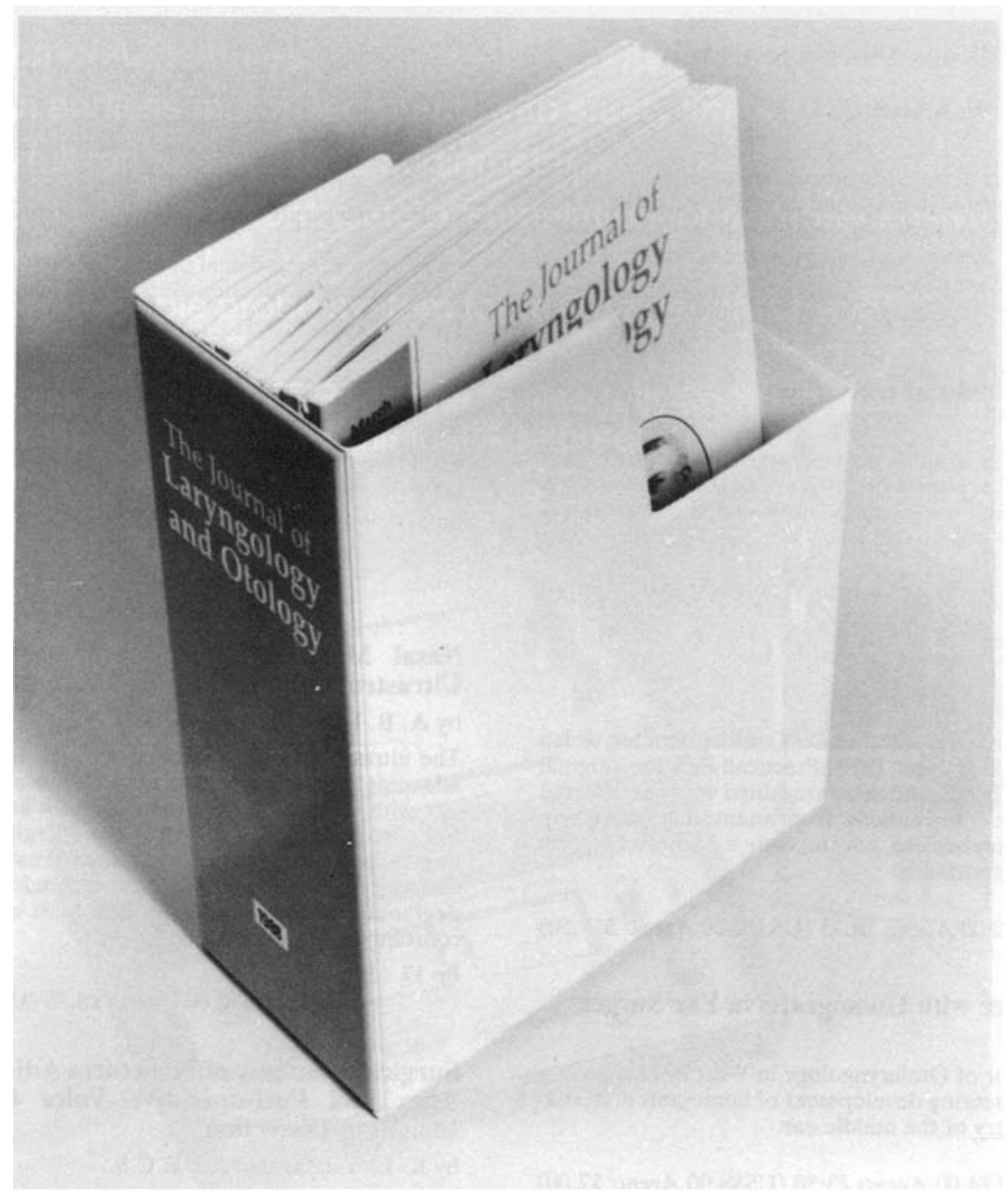

Bound in blue and white rexine to hold one volume. Available, boxed, from the Publisher price $£ 12$ including VAT and postage HEADLEY BROTHERS LTD, Queens Road Ashford Kent. 


\section{Laryngology \& Otology Publications}

\section{Available from the Publishers and from Agents throughout the world. \\ Prices include postage and packing.}

The Journal of Laryngology and Otology

Edited by John B. Booth

A leading international journal, published monthly and containing original scientific articles and clinical records in all fields of Otology, Rhinology and Laryngology. Including occasional supplements.

Founded in 1886.

Annual subscription for 1989 (calendar year): $£ 60.00$ Agents $£ 51.00$ (US\$150.00 Agents $\$ 127.50$ ); Students rate $£ 35.00$ (US\$90.00) ISSN 00222151

\section{Supplements still available separately.}

\section{Traité de L'Organe de L'Ouie}

by Nehemiah Asherson

This Bibliography of one of the earliest accurate descriptions of the organ of hearing, which first appeared in 1683, represents the culmination of a lifetime of historical research. It includes a biographical section on Du Verney, the author of the 'Traité'.

Pp 110 ISBN 0718604474

Retail $£ 7.00$ Agents $£ 6.12$ (US\$14.00 Agents $\$ 12.25$ )

The ENT Surgeon looks at the Orbit

by D. F. N. Harrison

This supplement records in some detail Professor Harrison's 'personal experience over a period of 20 years dealing with a wide variety of clinical conditions in which entry into the orbit was a desirable or essential part of treatment'.

Pp 42 Printed 1980

Retail $£ 4.00$ Agents $£ 3.50$ (US\$8.00 Agents $\$ 7.00$ )

\section{Tinnitus}

Chairman: Abraham Shulman

The Proceedings of The First International Tinnitus Seminar, which was held in New York in June 1979. Practically all the original papers are reproduced in full, and there are edited versions of all the Panel Discussions. The contributions, from an international group of experts, give comprehensive coverage to a subject of great current interest and importance.

Pp 216 Printed 1981

Retail 110.00 Agents $£ 8.75$ (US\$20.00 Agents $\$ 17.50$ )

\section{Years Experience with Homografts in Ear Surgery} by Christian Betow

The author, a professor of Otolaryngology in West Berlin, gives a full account of his pioneering development of homograft materials in reconstructive surgery of the middle ear.

Pp 28 Printed 1982

Retail $£ 4.00$ Agents $£ 3.50$ (US\$8.00 Agents $\$ 7.00$ )

\section{Laryngology Applied to Singers and Actors}

by Norman A. Punt

This fascinating monograph fills an obvious void in laryngological literature. The author, eminent in the field of vocal problems in theatre and opera house, writes with understanding, knowledge and concern. When mixed with valuable advice and useful prescriptions, this monograph will serve to guide all who find themselves called upon to help these most sensitive individuals.

Pp 24 Printed 1983

Retail $£ 4.00$ Agents $£ 3.50$ (US\$8.00 Agents $\$ 7.00$ )

Experimental and Clinical Studies in Otitis Media with Effusion

by Jamsheed A. Khan

An experimental and clinical study on the effects of Carbocisteine on fluid in the middle ear.

Pp 28 Printed 1983

Retail $£ 4.00$ Agents $£ 3.50$ (US\$8.00 Agents $\$ 7.00$ )
Proceedings of the Sixth British Academic Conference in Otolaryngology

Edited by John Ballantyne and John Booth

Pp 134 Printed 1983

Retail $£ 5.00$ Agents $£ 4.50$ (US\$10.00 Agents $\$ 7.50$ )

\section{Second International Tinnitus Seminar}

Chairman: Abraham Shulman

A comprehensive study of the problems and treatment of tinnitus. Pp 323 Printed 1984

Retail $£ 20.00$ Agents $£ 17.50$ (US\$40.00 Agents $\$ 35.00$ )

\section{Forensic Audiology}

by Chuang Wei Ping

A clear concise and practical guide to industrial hearing damage by a barrister/physician. This is an unusual and highly specialised aide memoire for the personal injuries practitioner, well illustrated with recent case law. A commendable enterprise by the author. Pp 57 Printed 1986

Retail $£ 7.00$ Agents $£ 6.12$ (US\$14.00 Agents $\$ 12.25$ )

\section{The Acute Orbit}

Preseptal (Periorbital) cellulitis subperiosteal abscess and orbital cellulitis due to sinusitis.

by J. R. Moloney, N. J. Badham and A. McRae

Pp 18 Printed 1987

Retail $£ 7.00$ Agents $£ 6.12$ (US\$14.00 Agents $\$ 12.25$ )

Nasal Mast Cells: A Preliminary Report on their Ultrastructure

by A. B. Drake-Lee, F.R.C.S.

The ultrastructural morphology of mast cells in the nose and the adenoids are compared. Normal cells have a very varied morphology with electron dense granules which have scrolls occasionally. Cells from patients with perennial allergic rhinitis show variable degranulation in all areas examined. Few cells were seen in the surface epithelium. Cells from the adenoids had different degrees of degranulation which suggests that mast cell reactions are not a constant feature.

Pp 17 Printed 1987

Retail $£ 10.00$ Agents $£ 8.75$ (US\$20.00 Agents $\$ 17.50$ )

Surgical Anatomy of Structures Adjacent to the Thyroid Apex and Post-operative Voice Change (A Review Including Dissection)

by K. L. Yerzingatsian, F.R.C.S.

Pp 13 Printed 1987

Retail $£ 10.00$ Agents $£ 8.75$ (US\$20.00 Agents $\$ 17.50$ )

Inferior Meatal Anstrostomy Fundamental Considerations of Design and Function

by Valerie Joan Lund, M.S., F.R.C.S.

Pp 18 (Contains $12 \times 4$ colour illustrations) Printed 1988 Retail $£ 15.00$ Agents $£ 13.12$ (US\$30.00 Agents $\$ 26.25$ )

Surgical Management of the Discharging Mastoid Cavity by R. P. Mills, M.Phil., F.R.C.S

Pp 6 Printed 1988

Retail $£ 10.00$ Agents $£ 8.75$ (US\$20.00 Agents $\$ 17.50$ )

Acquired Subglottic Stenosis

by C. M. Bailey, B.Sc., F.R.C.S.

Pp 48 Printed 1988

Retail $£ 12.00$ Agents $£ 10.50$ (US\$24.00 Agents $\$ 21.00$ ) 


\section{$1+1=1$}

Well, not always - but when Kamplex decide to combine two of their most versatile instruments into one compact package, the results add up to unrivalled value for money and convenience in clinical impedance instrumentation.

The Combi AZ comprises the popular Kamplex AZ7 Impedance Audiometer and the AG3 XYT Recorder - models which Audiology Departments around the world have come to trust for reliable and accurate clinical impedance measurements.

\section{The Combi AZ features:}

- An endless motorised pump with safety limits

- A full range, pure tone audiometer

- Ipsilateral and contralateral stimulation for comprehensive reflex testing

- A removable probe system for testing neonates and young children

- The precision XYT Recorder is also fully compatible with the Kamplex AC5/ABJ6 Clinical Audiometer printout functions

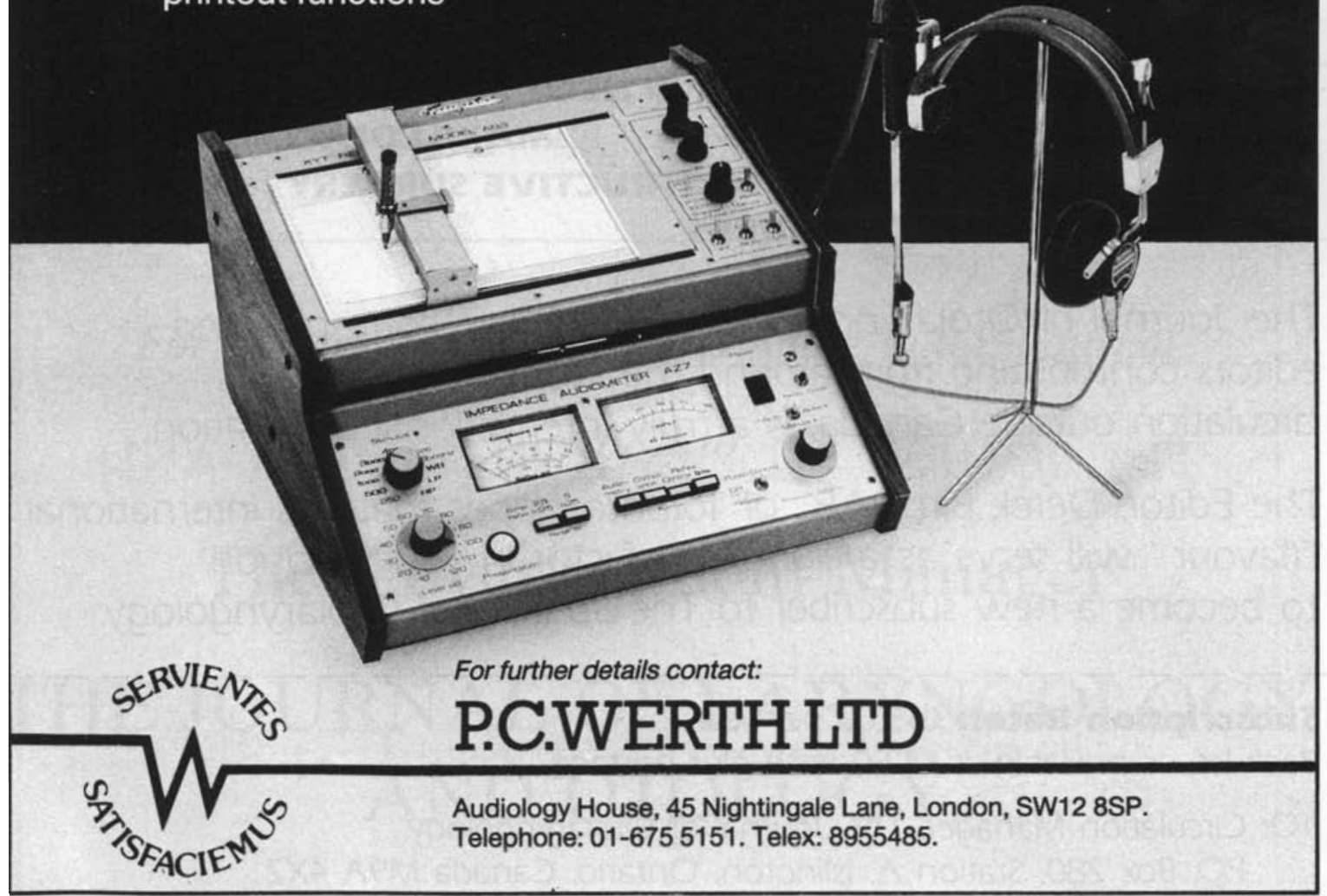




\section{The Journal of Otolaryneolosy}

...the official "voice" of

The Canadian Society of Otolaryngology Head and Neck Surgery

is published in February, April, June, August, October and December

Established in 1972, The Journal of Otolaryngology publishes original papers dealing with clinical and research aspects of otolaryngology in its broadest sense, including:

\section{AUDIOLOGY $\square$ HEAD AND NECK SURGERY BRONCHO-OESOPHAGOLOGY $\square$ MAXILLOFACIAL SURGERY \\ FACIAL PLASTIC AND RECONSTRUCTIVE SURGERY COMMUNICATIVE DISORDERS}

The Journal of Otolaryngology, with thirteen corresponding editors contributing from around the world and half of its circulation outside Canada, is a truly international publication.

The Editor, Derek Birt, M.B., of Toronto, hopes that this international "flavour" will serve as a significant factor in your decision to become a new subscriber to The Journal of Otolaryngology.

Subscription Rates: $£ 45.00$ per year

Back Issues available at $£ 4.50$ each plus postage

TO: Circulation Manager, The Journal of Otolaryngology

P.O. Box 280, Station A, Islington, Ontario, Canada M9A 4X2

I enclose a cheque for $\mathfrak{f}$ to cover

subscription(s) to The Journal of Otolaryngology.

NAME:

ADDRESS: 


\title{
THE LARYNGOSCOPE
}

\author{
A Monthly Journal \\ devoted to the disease of \\ EAR, NOSE AND THROAT \\ Official organ for the American Laryngological \\ Rhinological and Otological Society
}

Price $\$ 90.00$ per year

Canada $\$ 110.00$ per year

Foreign $\$ 110.00$ per year

ESTABLISHED 1896

Gershon J. Spector EDITOR

9216 CLAYTON ROAD, SUITE 18, ST. LOUIS, MISSOURI 63124-1561

For Advertisement Rates and Space in this Journal apply to

\section{The Advertisement Manager}

\section{THE JOURNAL OF LARYNGOLOGY AND OTOLOGY}

Headley Brothers Limited

The Invicta Press · Ashford · Kent TN24 8HH

Tel: (0233) 623131 


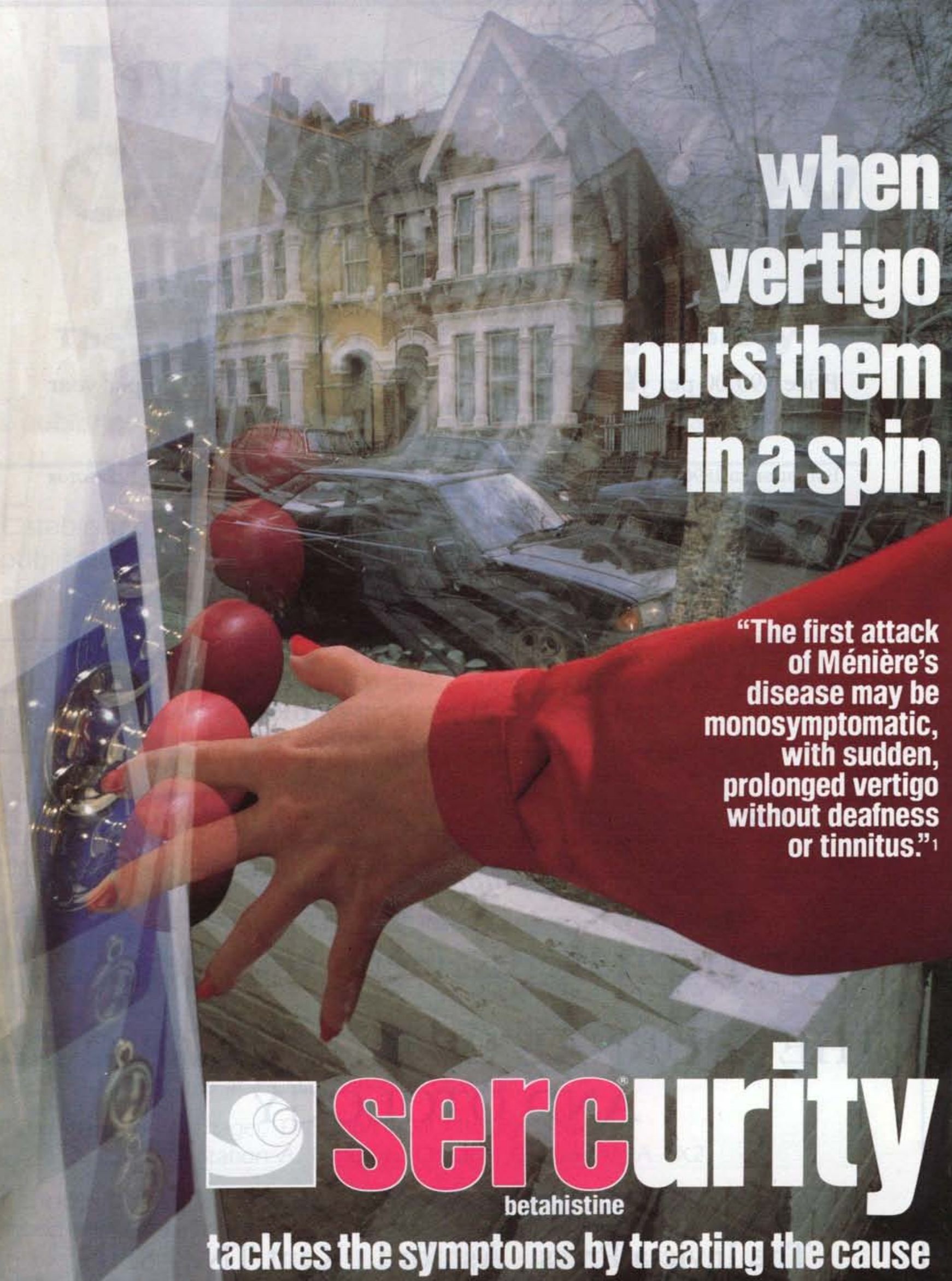

Presentation

White tablets containing $8 \mathrm{mg}$

betahistine dilhydrochloride. Available in packs of 120 tablets. Basic NHS price $\$ 12.88$

Vertigo, tinnitus and hearing loss associated with Ménière's syndrome Dosane and Administration

Adults Initially two tablets three time daily, taken preterabily with meaks Maintenance dose 3.6 tablets daily
Contra-indications, Warnings, etc. Contra-indications

recalidons. Clinical intolerance to Serc in bronchial asthma patients has not been shiown, but caution should be exercised when administering this histamine analogue to bronchial asthm? patients Interaction between Serc and antihistamines is theoretically possibte but no reports have been received. The usual precautions should be observed when administering Serc to patients in pregnancy
Side effects There has been a smal number of reports of gastric unset Product Licence Number 051220076

Reference:

I Venna N Geriatric Mext 1986

September: 17-22

duphar

Further information is available from ouphar Laboratories Limited. Gaters Hili, West End Southampton S0330 Eel 0703$) 47228$ 